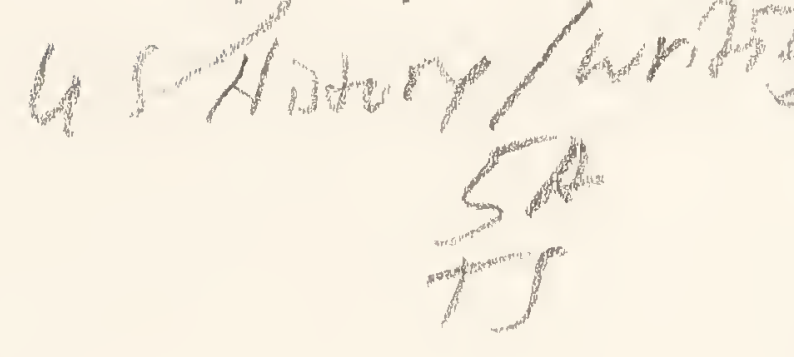

THE PAST BEFORE US 



\title{
THE PAST BEFORE US
}

Contemporary Historical Writing in the United States PAD

\author{
EDITED FOR THE
}

AMERICAN HISTORICAL ASSOCIATION ву MICHAEL KAMMEN

Cornell University Press ITHACA AND LONDON 


\section{Copyright (C) 1980 by Cornell University}

All rights reserved. Except for brief quotations in a review, this book, or parts thereof, must not be reproduced in any form without permission in writing from the publisher. For information address Cornell University Press, 124 Roberts Place, Ithaca, New York $14^{8} 5^{\mathrm{o}}$.

First published 1980 by Cornell University Press. Published in the United Kingdom by Cornell University Press Ltd., 2-4 Brook Street, London W 1 Y 1 AA.

International Standard Book Number 0-8014-1224-2 Library of Congress Catalog Card Number $79^{-25785}$

Printed in the United States of America

Librarians: Library of Congress cataloging information appears on the last page of the book.

This volume of essays was prepared for presentation on the occasion of the Fifteenth International Congress of Historical Sciences, held in Bucharest, Romania, August 1980. 
Perhaps the mass of students are more skeptical now than they were thirty years ago of the possibility that such a science [of history] can be created. Yet almost every successful historian has been busy with it, adding here a new analysis, a new generalization there; a clear and definite connection where before the rupture of idea was absolute; and, above all, extending the field of study until it shall include all races, all countries, and all times. Like other branches of science, history is now encumbered and hampered by its own mass, but its tendency is always the same, and cannot be other than what it is. That the effort to make history a science may fail is possible, and perhaps probable; but that it should cease, unless for reasons that would cause all science to cease, is not within the range of experience. Historians will not, and even if they would they can not, abandon the attempt.

-Henry Adams, "The Tendency of History," an open letter to the American Historical Association, dated December 12, 1894, while Adams was president of the Association

In the history of history a myth is a once valid but now discarded version of the human story, as our now valid versions will in due course be relegated to the category of discarded myths. With our predecessors, the bards and storytellers and priests, we have therefore this in common: that it is our function, as it was theirs, not to create, but to preserve and perpetuate the social tradition; to harmonize, as well as ignorance and prejudice permit, the actual and the remembered series of events; to enlarge and enrich the specious present common to us all to the end that "society" (the tribe, the nation, or all mankind) may judge of what it is doing in the light of what it has done and what it hopes to do.

-Carl Becker, "Everyman His Own Historian" (1932) 
Digitized by the Internet Archive in 2017 with funding from

China-America Digital Academic Library (CADAL) 